\title{
PENGARUH MODEL TSTS MELALUI LESSON STUDY TERHADAP HASIL BELAJAR IPA
}

\author{
Juni Harta ${ }^{1}$, I Ketut Dharsana ${ }^{2}$, Ndara Tanggu Renda ${ }^{3}$ \\ 1,2, Jurusan PGSD, 2 Jurusan BK,Fakultas IImu Pendidikan \\ Universitas Pendidikan Ganesha \\ Singaraja, Indonesia
}

e-mail: juniharta52@gmail.com ${ }^{1}$,profdarsana@yahoo.com ${ }^{2}$, ndaratanggu.renda@undiksha.ac.id ${ }^{3}$

\begin{abstract}
Abstrak
Penelitian ini bertujuan untuk mengetahui perbedaan yang signifikan hasil belajar IPA antara siswa yang belajar melalui pembelajaran dengan model pembelajaran Kooperatif Tipe TSTS melalui Lesson Study dan siswa yang dibelajarkan tidak dengan model pembelajaran Kooperatif Tipe Two Stay Two Stray melalui Lesson Study pada siswa kelas V Sekolah Dasar di Gugus XV Kecamatan Buleleng. Jenis penelitian ini adalah penelitian eksperimen semu dengan rancangan post test only control group design. Populasi penelitian ini adalah seluruh kelas V SD di Gugus XV Kecamatan Buleleng. Sampel diambil dengan teknik random sampling sehingga diperoleh kelas V SDN 2 Anturan sebagai kelompok eksperimen dan V SDN 3 Kalibukbuk sebagai kelompok kontrol. Pengumpulan data dilakukan dengan tes hasil belajar IPA yang berupa tes objektif. Data dianalisis menggunakan statistik deskriptif dan Independent Sample t-test. Besarnya thitung adalah 2,17, sedangkan ttabel pada taraf signifikansi $5 \%$ dan db $=55$ adalah 2,021. Hal ini berarti, thitung lebih besar dari ttabel (thitung $>$ ttabel). Di samping itu, rata-rata skor hasil belajar IPA siswa yang belajar dengan model pembelajaran Kooperatif Tipe TSTS melalui Lesson Study $(24,03)$ lebih tinggi dari pada siswa yang dibelajarkan tidak dengan model pembelajaran Kooperatif Tipe TSTS melalui Lesson Study $(20,08)$. Dengan demikian, model pembelajaran Kooperatif Tipe Two Stay Two Stray melalui Lesson Study berpengaruh terhadap hasil belajar IPA pada siswa kelas $V$ Semester Genap SDN 2 Anturan Kecamatan Buleleng.
\end{abstract}

Kata kunci: tsts, lesson study, hasil belajar..

\begin{abstract}
This study aims to determine the significant difference of science learning outcomes between students learning through learning with cooperative learning model TSTS type through Lesson Study and students who were taught not with Cooperative Type Two Stay Two Stray learning model through Lesson Study in grade $V$ students of Elementary School District Cluster XV Buleleng District. This type of this quasi experiment research with post test only control group design design. The population of this study were all of $\mathrm{V}$ class SD in cluster XV Buleleng District. The sample was taken by random sampling technique so that it was obtained by V class SDN 2 Anturan as experimental group and $\mathrm{V}$ class of SDN 3 Kalibukbuk as control group. The data collection was done by science learning result test in the form of objective test. Data were analyzed using descriptive statistic and Independent Sample t-test. The thitung is 2.17, while the ttabel at the 5\% significance level and $\mathrm{db}=55$ is 2.021. It means, thitung is higher than ttabel (thitung > ttabel). In addition, the average score of learning outcomes of students who studied with TSTS Cooperative learning model through Lesson Study (24.03) was higher than the students who were not taught with cooperative learning model TSTS type through Lesson Study (20.08) . Thus, the Cooperative Type Two Stay Two Stray learning model through Lesson Study has an effect on the science learning outcomes of the $\mathrm{V}$ grade students of the second semester of SDN 2 Anturan Buleleng District.
\end{abstract}

Keywords: tsts, lesson study, learning outcomes. 


\section{Pendahuluan}

Pada Undang-undang No. 20 tahun 2003 tentang Sistem Pendidikan Nasional, Pasal 37 Ayat 1 menyebutkan bahwa kurikulum pada jenjang pendidikan dasar dan menengah wajib memuat 10 mata pelajaran. Salah satunya ialah Ilmu Pengetahuan Alam (IPA). Menurut (Trianto, 2007:99) "IPA bukan hanya penguasaan kumpulan pengetahuan yang berupa faktafakta, atau prinsip-prinsip saja, tetapi juga merupakan suatu proses penemuan". Artinya, IPA merupakan sebuah ilmu yang berhubungan dengan cara mencari tahu informasi tentang alam secara sistematis melalui proses penemuan. Dengan demikian, pendidikan IPA diharapkan dapat menjadi wahana bagi siswa untuk mempelajari diri sendiri, alam sekitar, prospek pengembangan lebih lanjut, dan penerapannya di dalam kehidupan sehari-hari.

Melihat pentingnya IPA bagi siswa seperti dipaparkan di atas, seharusnya proses pembelajaran IPA menekankan pada pemberian pengalaman langsung agar kompetensi siswa dapat menjelajahi dan memahami alam sekitar secara alamiah. "Cakupan IPA yang dipelajari di sekolah tidak hanya berupa kumpulan fakta, tetapi juga proses perolehan fakta yang didasarkan pada kemampuan menggunakan pengetahuan dasar IPA untuk memprediksi atau menjelaskan berbagai fenomena yang berbeda" (Susanto, 2013). Tujuan pembelajaran IPA disekolah dasar dalam badan nasional standar pendidikan (BSNP, 2006) salah satunya pengembangan rasa ingin tahu sikap positif dan kesadaran tentang adanya hubungan yang saling mempengaruhi antara IPA, lingkungan dan masyarakat.

Untuk mencapai tujuan tersebut pembelajaran IPA di SD harus sesuai dengan karakteristik siswanya yang masih berada pada tahap oprasional konkret, yang belum bisa berpikir abstrak dan memiliki karakteristik yang beragam. Pembelajaran IPA di SD hendaknya dirancang agar sesuai dengan kebutuhan siswanya yang sesuai dengan karakteristik siswa SD. Dengan demikian kualitas hasil belajar IPA akan meningkat, namun kenyataannya belum mencapai hasil belajar yang diharapkan.

Berdasarkan hasil wawancara, observasi dan studi dokumen yang dilakukan pada tanggal 24 November 2017 dengan guru kelas V di SDN 2 Anturan Kecamatan Buleleng, hasil wawancara yang diperoleh yaitu dalam proses pembelajaran IPA masih banyak siswa yang kurang aktif dalam mengikuti pembelajaran IPA dan mudah bosan pada saat menerima pembelajaran dikelas. Siswa juga masih sulit memahami konsep IPA dan siswa kurang termotivasi dalam mengikuti pembelajaran dikelas. Dilanjutkan dengan observasi pada saat guru melaksanakan pembelajaran IPA di kelas mendapatkan hasil yaitu : (1) Pembelajaran yang dilaksanakan di kelas masih menggunakan pembelajaran yang berpusat pada guru dengan menggunakan metode ceramah. (2) Dalam pelaksanaan pembelajaran terutama mata pelajaran IPA, penggunaan media pembelajaran yang diterapkan oleh guru kurang bervariasi sehingga membuat siswa merasa bosan. Hal tersebut akan berpengaruh terhadap hasil belajar IPA yang diperoleh siswa menjadi kurang baik.

Berdasarkan hasil studi dokumen, tentang nilai Ulangan Tengah Semester (UTS) kelas V mata pelajaran IPA di SD Gugus XV Kecamatan Buleleng tahun pelajaran 2017/2018 terdapat pada tabel 1.

Tabel 1. Nilai Rata-rata UTS IPA Siswa kelas V SD di Gugus XV Kecamatan Buleleng Tahun Pelajaran 2017/2018

\begin{tabular}{llll}
\hline No. & Nama Sekolah & $\begin{array}{l}\text { Nilai } \\
\text { siswa Kelas V }\end{array}$ & $\begin{array}{c}\text { Rata-rata } \\
\text { Jumlah Siswa }\end{array}$ \\
\hline 1 & SDN 1 Anturan & 56,82 & 23 \\
2 & SDN 2 Anturan & 64,81 & 33 \\
3 & SDN 3 Anturan & 59,51 & 29 \\
4 & SD Tri Amerta & 56,89 & 21 \\
5 & SDN 1 Kalibukbuk & 57,60 & 28
\end{tabular}




\begin{tabular}{llll}
6 & SDN 2 Kalibukbuk & 56,14 & 34 \\
7 & SDN 3 Kalibukbuk & 55,54 & 24 \\
8 & SDN 4 Kalibukbuk & 55,56 & 39 \\
Total & & & 231 \\
\hline
\end{tabular}

Berdasarkan tabel 1, maka dapat diketahui bahwa nilai rata-rata siswa yang ada di SD Gugus XV Kecamatan Buleleng seluruhnya berada dibawah KKM. KKM di Gugus XV Kecamatan Buleleng adalah 75, dimana SDN 3 Kalibukbuk memiliki nilai rata-rata terendah yaitu 55,54 dan tertinggi di SDN 2 Anturan yaitu 64,81. Hal ini merupakan suatu masalah yang harus di atasi agar hasil belajar siswa menjadi lebih baik.

Untuk itu alternatif yang dapat mengatasi masalah diatas perlu diterapkannya berbagai jenis pendekatan, strategi dan model pembelajaran. Salah satu model pembelajaran yang dapat digunakan untuk mengatasi permasalahan diatas adalah model pembelajaran kooperatif tipe Two Stay Two Stray. Model pembelajaran kooperatif tipe Two Stay Two Stray merupakan model pembelajaran yang dilakukan secara berkelompok dimana siswa diajarkan untuk bekerja sama saling bertukar informasi dengan kelompok-kelompok lain. Sejalan dengan pendapat (Huda, 2014:207) menyatakan bahwa model pembelajaran kooperatif tipe Two Stay Two Stray merupakan sistem pembelajaran kelompok dengan tujuan agar siswa dapat saling bekerja sama, bertanggung jawab, saling membantu memecahkan masalah, dan saling mendorong satu sama lain untuk berprestasi. Selain penggunaan model pembelajaran kooperatif tipe Two Stay Two Stray, Guru sebagai seorang individu dalam meningkatkan kemampuan pengelolaan kelas dan interaksi kelas, tentunya memerlukan bantuan dari orang lain. Guru dalam membangun pengetahuan tentang cara meningkatkan kemampuan pengelolaan dan kualitas interaksi dapat melalui belajar secara kolaboratif. Salah satu bentuk pembinaan profesi guru secara kolaboratif dapat melalui lesson study. Menurut (Daryanto, 2012:42) menyatakan bahwa Lesson Study merupakan suatu model pembinaan profesi pendidik melalui pengkajian pembelajaran secara kolaboratif dan berkelanjutan berlandaskan prinsip-prinsip kolegalitas dan mutual learning untuk membangun komunitas belajar.

Dari penelitian yang sebelumnya yang dilakukan oleh (Cici Fitrayatun Karlina, 2017) menyatakan bahwa jika model pembelajaran TSTS dilakukan melalui Lesson Study dengan baik maka pelaksanaan pembelajaran tersebut akan lebih efektif sesuai dengan sintak pembelajarannya, karena melalui lesson study perencanaan pembelajaran secara teliti disiapkan termasuk media pembelajaran dan instrumen penilaian. Sehingga melalui lesson study akan banyak mendapatkan saran-saran yang diperoleh untuk perbaikan pembelajaran berikutnya.

Berdasarkan penjelasan di atas, maka perlu dilakukan suatu penelitian eksperimen dengan judul " Pengaruh Model Pembelajaran Kooperatif Tipe Two Stay Two Stray Terhadap Hasil Belajar IPA Melalui Lesson Study Pada Siswa Kelas V Semester Genap Di SDN 2 Anturan Kecamatan Buleleng Tahun Pelajaran 2017/2018".Tujuan dari penelitian ini yaitu : untuk mengetahui perbedaan hasil belajar IPA antara siswa yang dibelajarkan dengan model pembelajaran kooperatif tipe Two Stay Two Stray melalui Lesson Study dengan siswa yang tidak dibelajarkan dengan model pembelajaran kooperatif tipe Two Stay Two Stray melalui Lesson Study pada siswa kelas V Semester Genap di SDN 2 Anturan Kecamatan Buleleng Tahun Pelajaran 2017/2018.

\section{Metode}

Tempat pelaksanaan penelitian ini adalah di SDN 2 Anturan Kecamatan Buleleng, Kabupaten Buleleng pada rentang waktu semester II (genap) tahun pelajaran 2017/2018. Penelitian ini merupakan penelitian eksperimen semu (quasi experiment), dengan menggunakan rancangan atau desain post-test only control group design. Adapun desain dari penelitian dapat dilihat pada tabel 2. 
Tabel 2. Desain Post-test Only Control Group Design

\begin{tabular}{ccc}
\hline Kelas & Treatment & Post-test \\
\hline $\operatorname{Re}$ & $X$ & $O_{1}$ \\
$\operatorname{Rk}$ & - & $O_{2}$ \\
\hline
\end{tabular}

(Dantes, 2012:96)

Populasi dalam penelitian ini adalah seluruh siswa SD kelas V di Gugus XV Kecamatan Buleleng. Adapun sekolah dasar yang terdapat di Gugus XV Kecamatan Buleleng yaitu SDN 1 Anturan, SDN 2 Anturan, SDN 3 Anturan, dan SD Tri Amerta, SDN 1 Kalibukbuk, SDN 2 Kalibukbuk, SDN 3 Kalibukbuk, SDN 4 Kalibukbuk. Pengambilan sampel dalam penelitian ini menggunakan teknik random sampling pada siswa kelas V. Sebelum melakukan random sampling terlebih dahulu dilakukan tahapan uji kesetaraan dengan tujuan untuk mengetahui kemampuan akademik dari seluruh siswa kelas V SD di Gugus XV Kecamatan Buleleng dengan menggunakan uji anava satu jalur. Hasil uji kesetaraan dapat dilihat pada Tabel 3.

Tabel 3. Hasil Uji Kesetaraan

\begin{tabular}{ccccccc}
\hline Sumber Variasi & JK & $\mathrm{db}$ & $\mathrm{RJK}$ & $\mathrm{F}_{\text {hitung }}$ & $\begin{array}{c}\mathrm{F}_{\text {tab }} \\
(5 \%)\end{array}$ & Keputusan \\
\hline Antar & 2244,79 & 7 & 320,68 & 0,0004 & 2,05 & Signifikan \\
Dalam & $179.053 .880,48$ & 23 & $802022,, 80$ & - & - & - \\
Total & $179.076 .328,27$ & 230 & - & - & - & - \\
\hline
\end{tabular}

Berdasarkan hasil analisis Anava Satu Jalur pada taraf signifikan 5\% diperoleh nilai

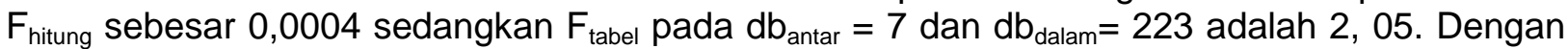
demikian terlihat bahwa nilai $\mathrm{F}_{\text {hitung }}<\mathrm{F}_{\text {tabel }}\left(0,003<2\right.$, 05), sehingga $\mathrm{H}_{0}$ diterima dan $\mathrm{H}_{1}$ ditolak. Jadi, terdapat perbedaan hasil ulangan tengah semester (UTS) tahun pelajaran 2017/2018 mata pelajaran IPA siswa kelas V SD di Gugus XV Kecamatan Buleleng. Setelah diperoleh hasil perhitungan uji kesetaraan, selanjutnya dirandom untuk menentukan kelas eksperimen dan kelas kontrol. Hasil dari random tersebut kelas V SDN 2 Anturan terpilih sebagai kelompok eksperimen yang akan diberikan perlakuan menggunakan model pembelajaran kooperatif tipe TSTS melalui Lesson Study dan kelas V di SDN 3 Kalibukbuk sebagai kelompok kontrol dengan pembelajaran konvensional. Data yang dikumpulkan dalam penelitian ini adalah data hasil belajar IPA siswa kelas V yang merupakan variabel terikat dalam penelitian ini. Instrumen yang digunakan dalam penelitian ini yaitu tes objektif yang berjumlah 30 butir soal. Soal posttest sebelum digunakan terlebih dahulu diuji validitas, reliabilitas, tingkat kesukaran, dan daya beda dari instrumen yang dibuat. Kemudian post-test diberikan pada kelompok eksperimen dan kelompok kontrol. Hasil dari post-test yang diberikan tersebut akan dianalisis guna untuk menjawab hipotesis dalam penelitian ini.

Pengujian dalam hipotesi ini menggunakan uji-t (independent $t$-test). Sebelum dilakukan pengujian hipotesis terlebih dahulu data yang di analisis harus memenuhi syarat analisis yang terdiri dari uji normalitas sebaran data dan uji homogenitas varian. Setelah data yang dianalisis tersebut berdistribusi normal dan homogen maka selanjutnya akan dilakukan uji hipotesis menggunakan uji t, untuk mengetahui perbedaan hasil belajar IPA antara siswa kelas $\mathrm{V}$ yang mengikuti pembelajaran dengan menggunakan model pembelajaran kooperatif tipe Two Stay Two Stray melalui lesson study dengan siswa yang tidak mengikuti pembelajaran kooperatif tipe Two Stay Two Stray melalui lesson study pada siswa kelas V SDN 2 Anturan Kecamatan Buleleng Tahun Pelajaran 2017/2018. 


\section{Hasil dan Pembahasan}

Hasil penelitian ini menunjukkan bahwa terdapat perbedaan hasil belajar IPA antara siswa yang mengikuti pembelajaran dengan menggunakan model pembelajaran kooperatif tipe Two Stay Two Stray melalui lesson study dengan siswa yang tidak mengikuti pembelajaran kooperatif tipe Two Stay Two Stray melalui lesson study pada siswa kelas V SDN 2 Anturan Kecamatan Buleleng Tahun Pelajaran 2017/2018. Hal ini dapat dilihat dari hasil belajar IPA yang dicapai oleh siswa. Hasil analisis statistik deskriptif data penelitian ini disajikan pada tabel 4.

Tabel 4. Analisis Data dengan Statistik Deskriptif

\begin{tabular}{ccc}
\hline Data & Eksperimen & Kontrol \\
\hline Mean & 24,03 & 20,08 \\
Median & 24,55 & 20 \\
Modus & 26,21 & 19,83 \\
Standar Deviasi & 4,32 & 4,58 \\
Varians & 18,71 & 21,03 \\
\hline
\end{tabular}

Berdasarkan data pada tabel di atas, menunjukkan bahwa data hasil belajar IPA kelomppok eksperimen disajikan dalam bentuk kurva polygon seperti gambar 1

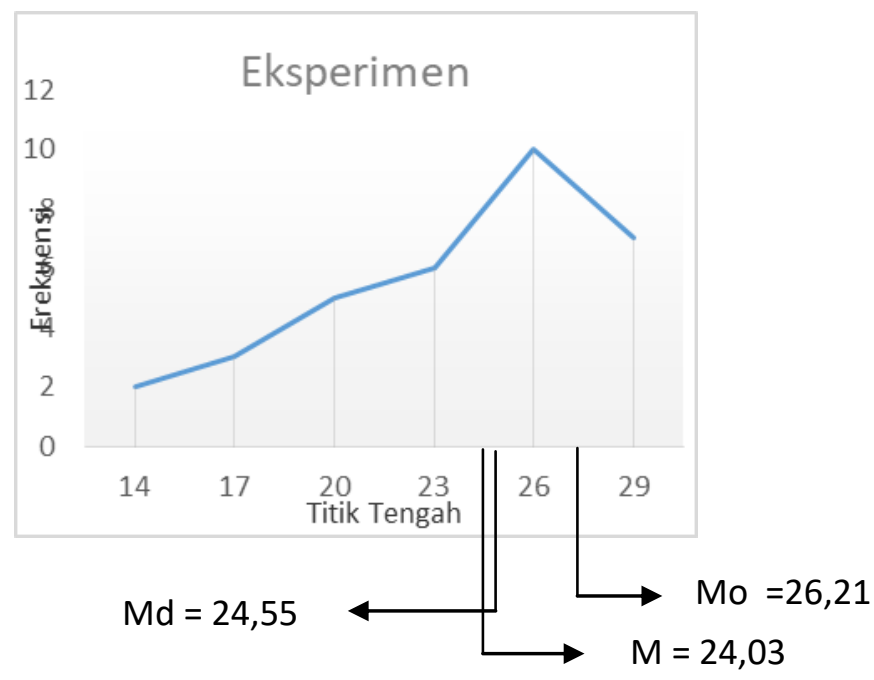

\section{Gambar 1. Kurva Poligon Data Hasil Belajar IPA Siswa Kelompok Eksperimen}

Berdasarkan Gambar 1, tampak bahwa sebaran data kelompok siswa yang mengikuti model pembelajaran kooperatif tipe TSTS melalui Lesson Study merupakan kurva juling negatif karena Mo > Md > M (26,21 > 24,55 > 24,03). Hal ini menunjukkan bahwa sebagian besar skor siswa kelompok esperimen cenderung sangat tinggi. Kecenderungan skor ini dapat dibuktikan dengan melihat frekuensi relatif pada tabel distribusi frekuensi. Frekuensi relatif skor yang berada di atas rata-rata lebih besar dibandingkan frekuensi relatif skor yang berada dibawah

rata-rata. Sedangkan data hasil belajar siswa kelas kontrol disajikan pada gambar 2 . 


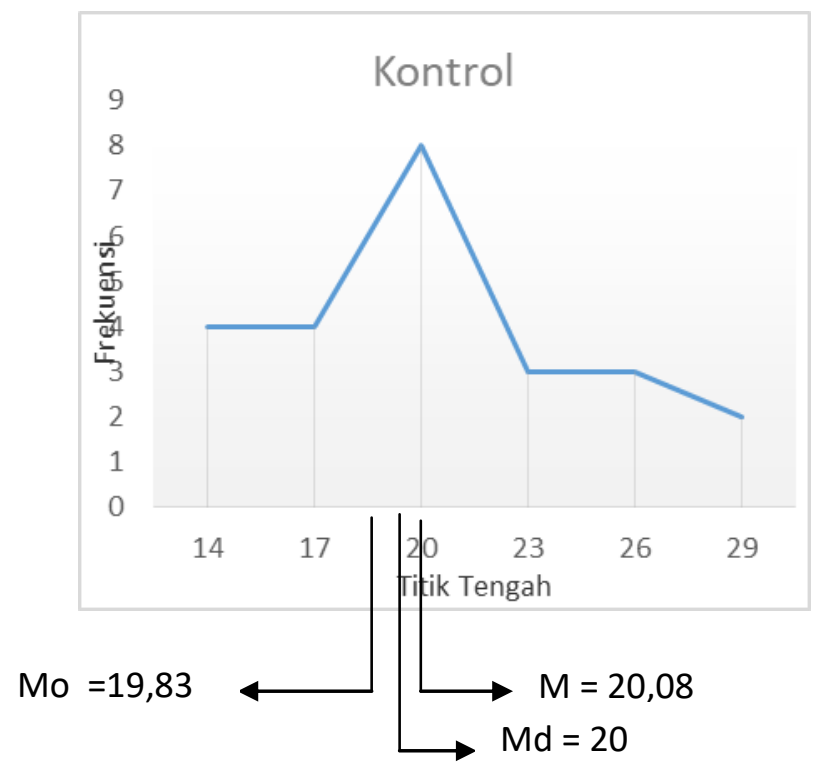

\section{Gambar 2. Kurva Poligon Data Hasil Belajar IPA Siswa Kelompok Kontrol}

Gambar 2 menunjukkan bahwa kurva sebaran data kelompok siswa yang pembelajaran konvensional berupa kurva juling positif karena $M o<M d<M(19,83<20<20,08)$. Hal ini menunjukkan bahwa sebagian besar skor siswa kelompok kontrol cenderung tinggi. Kecenderungan skor ini dapat dibuktikan dengan melihat frekuensi relatif pada tabel distribusi frekuensi. Frekuensi relatif skor yang berada di atas rata-rata lebih kecil dibandingkan frekuensi relatif skor yang berada dibawah rata-rata. Setelah melakukan analisis statistik deskriptif, selanjutnya dilakukan uji prasyarat untuk menguji hipotesis. Uji prasyarat yang dilakukan adalah uji normalitas dan homogenitas. Uji normalitas data dilakukan terhadap data hasil belajar IPA kelompok eksperimen dan kontrol. Berdasarkan analisis data yang dilakukan, dapat disajikan hasil uji normalitas sebaran data hasil belajar IPA kelompok eksperimen dan kontrol pada Tabel 5.

Tabel 5. Hasil Uji Normalitas Sebaran Data Hasil Belajar IPA

\begin{tabular}{|c|c|c|c|c|}
\hline No & $\begin{array}{l}\text { Kelompok Data Hasil } \\
\text { belajar IPA }\end{array}$ & $x^{2}$ & $\begin{array}{l}\text { Nilai Kritis pada Taraf } \\
\text { Signifikansi } 5 \%\end{array}$ & Status \\
\hline & $\begin{array}{l}\text { Eksperimen } \\
\text { Kontrol }\end{array}$ & $\begin{array}{l}6,036 \\
3,598\end{array}$ & $\begin{array}{l}7,815 \\
7,815\end{array}$ & $\begin{array}{l}\text { Normal } \\
\text { Normal }\end{array}$ \\
\hline
\end{tabular}

Kriteria pengujian, jika $x_{\text {hitung }}^{2}<x_{\text {tabel }}^{2}$ dengan taraf signifikansi $5 \%(\mathrm{dk}=6-2-1)$, maka data berdistribusi normal. Berdasarkan hasil perhitungan dengan menggunakan rumus Chi Squre, diperoleh $x^{2}$ hitung skor hasil belajar IPA siswa kelompok eksperimen adalah 6,036 , sedangkan $x_{\text {tabel }}^{2}$ dengan taraf signifikansi $5 \%$ dan $\mathrm{db}=3$ adalah 7,815 . Hal ini berarti, $x^{2}$ hitung skor hasil belajar IPA siswa kelompok eksperimen lebih kecil dari $x_{\text {tabel }}^{2}\left(x_{\text {hitung }}^{2}<x_{\text {tabel }}^{2}\right.$ ), sehingga data hasil belajar IPA siswa kelompok eksperimen berdistribusi normal. Selanjutnya, $x_{\text {hitung }}^{2}$ skor hasil belajar IPA siswa kelompok kontrol adalah 3,598 dan $x_{\text {tabel }}^{2}$ dengan taraf signifikansi $5 \%$ dan $\mathrm{db}=3$ adalah 7,815 . Hal ini berarti, $x^{2}$ hitung data hasil belajar kelompok kontrol lebih kecil dari $x_{\text {tabel }}^{2}\left(x_{\text {hitung }}^{2}<x_{\text {tabel }}^{2}\right)$, sehingga data hasil belajar IPA siswa kelompok kontrol berdistribusi normal. Selanjutnya, uji homogenitas dilakukan terhadap varians pasangan antara kelompok eksperimen dan kelompok kontrol. Hasil uji homogenitas varians antara kelompok eksperimen dan kelompok kontrol disajikan pada tabel 6 . 
Tabel 6. Hasil Uji Homogenitas Kelompok Eksperimen dan Kontrol

\begin{tabular}{cccc}
\hline $\begin{array}{c}\text { Kelompok Data Hasil belajar } \\
\text { IPA }\end{array}$ & F-hitung & $\begin{array}{l}\text { F-tabel dengan Taraf } \\
\text { Signifikansi 5\% }\end{array}$ & Status \\
\hline $\begin{array}{c}\text { Eksperimen } \\
\text { Kontrol }\end{array}$ & 1,12 & 2,08 & Homogen \\
\hline
\end{tabular}

Berdasarkan tabel di atas, diketahui $F_{\text {hitung }}$ skor hasil belajar IPA siswa kelompok eksperimen dan kontrol adalah 1,12, sedangkan $\mathrm{F}_{\text {tabel }}$ dengan $\mathrm{db}_{\text {pembilang }}=1 \mathrm{dan} \mathrm{db}_{\text {penyebut }}=56$ pada taraf signifikansi $5 \%$ adalah 2,08. Hal ini berarti, varians data hasil belajar IPA siswa kelompok eksperimen dan kontrol adalah homogen. Berdasarkan uji prasyarat analisis data, diperoleh bahwa data hasil post-test kelompok eksperimen dan kelompok kontrol adalah normal dan homogen. Setelah diperoleh hasil dari uji prasyarat analisis data, dilanjutkan dengan pengujian hipotesis penelitian $\left(\mathrm{H}_{1}\right)$ dan hipotesis nol $\left(\mathrm{H}_{0}\right)$. Pengujian hipotesis tersebut dilakukan dengan menggunakan uji-t dengan rumus polled varians dengan kriteria $\mathrm{H}_{0}$ tolak jika $t_{\text {hit }}>t_{t a b}$ dan $\mathrm{H}_{0}$ terima jika $t_{\text {hit }}<t_{\text {tab }}$. Rangkuman hasil perhitungan uji-t antara kelompok eksperimen dan kelompok kontrol disajikan pada tabel 7

Tabel 7. Ringkasan Hasil Uji Hipotesis

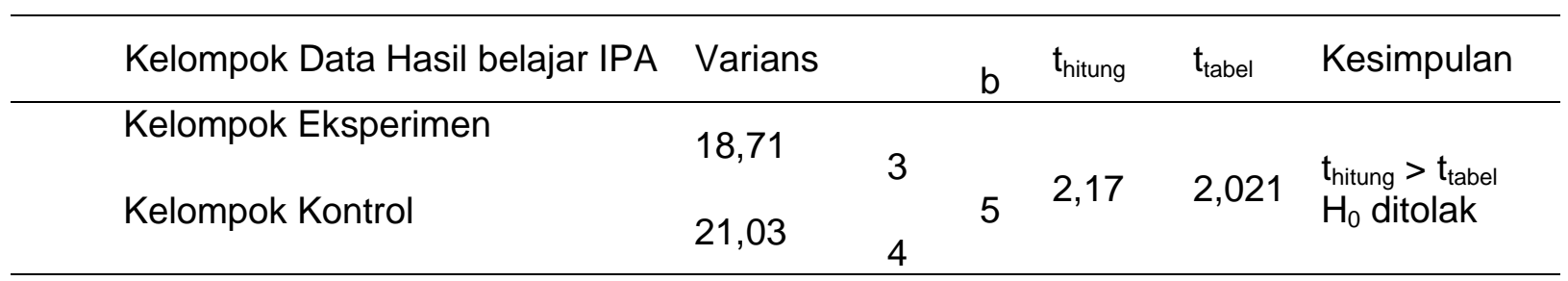

Berdasarkan tabel 7, tampak bahwa $t_{\text {hitung }}$ sebesar 2,17 , sedangkan, $t_{\text {tabel }}$ dengan $\mathrm{db}=56$ pada taraf signifikansi $5 \%$ adalah 2,021. Hal ini berarti, $t_{\text {hitung }}$ lebih besar dari $t_{\text {tabel }}\left(t_{\text {hitung }}>t_{\text {tabel }}\right)$ sehingga $\mathrm{H}_{0}$ ditolak dan $\mathrm{H}_{1}$ diterima. Dengan demikian, dapat diinterpretasikan bahwa terdapat perbedaan yang signifikan pada hasil belajar IPA antara siswa yang belajar dengan model pembelajaran kooperatif tipe TSTS melalui lesson study dan siswa yang tidak belajar dengan model pembelajaran kooperatif tipe TSTS melalui lesson study pada siswa kelas V Semester Genap Di SD Negeri 2 Anturan Kecamatan Buleleng Tahun Pelajaran 2017/2018.

Pada bagian pembahasan ini, dipaparkan mengenai perbedaan hasil belajar IPA antara siswa yang dibelajarkan dengan model pembelajaran kooperatif tipe TSTS melalui Lesson Study dan siswa yang tidak belajar dengan model pembelajaran kooperatif tipe TSTS melalui lesson study pada siswa kelas V Semester Genap Di SD Negeri 2 Anturan Kecamatan Buleleng Tahun Pelajaran 2017/2018. Sampel penelitian adalah siswa kelas V SDN 2 Anturan sebagai kelas eksperimen dan siswa kelas V SDN 3 Kalibukbuk sebagai kelas kontrol.

Secara deskriptif, hasil belajar IPA siswa kelompok eksperimen lebih tinggi dibandingkan dengan siswa kelompok kontrol. Tinjauan ini didasarkan pada rata-rata skor dan kecenderungan skor hasil belajar IPA yang diperoleh kedua kelompok. Rata-rata skor hasil belajar IPA siswa kelompok eksperimen adalah 24,03 (kategori sangat tinggi), sedangkan ratarata skor hasil belajar IPA siswa kelompok kontrol adalah 20,08 (kategori tinggi). Begitu pula yang tampak pada kurva poligon, yang mana sebaran data kelompok ini merupakan juling negatif. Artinya, sebagian besar skor siswa cenderung sangat tinggi. Namun berbeda halnya pada kelompok kontrol, kurva sebaran data merupakan juling positif, yang artinya sebagian besar skor siswa cenderung tinggi.

Berdasarkan analisis data menggunakan uji-t, diketahui $t_{\text {hitung }}=2,17$ dan $t_{\text {tabel }}(d b=55$ pada taraf signifikansi $5 \%)=2,021$. Hasil perhitungan tersebut menunjukkan bahwa $t_{\text {hitung }}$ lebih besar dari $t_{\text {tabel }}\left(t_{\text {hitung }}>t_{\text {tabel }}\right)$, sehingga hasil penelitian adalah signifikan. Hal ini berarti, terdapat perbedaan yang signifikan pada hasil belajar IPA antara siswa yang belajar dengan model 
pembelajaran kooperatif tipe TSTS melalui lesson study dan siswa yang tidak belajar dengan model pembelajaran kooperatif tipe TSTS melalui lesson study. Adanya perbedaan yang signifikan menunjukkan bahwa model pembelajaran kooperatif tipe TSTS melalui lesson study berpengaruh terhadap hasil belajar IPA siswa. Besarnya pengaruh model pembelajaran kooperatif tipe TSTS melalui lesson study dan yang tidak belajar dengan model pembelajaran kooperatif tipe TSTS melalui lesson study terhadap hasil belajar dapat dibuktikan dari hasil analisis deskriptif. Hasil analisis deskriptif menunjukkan bahwa rata-rata skor hasil belajar IPA kelompok eksperimen, yaitu 24,03 lebih tinggi daripada kelompok kontrol, yaitu 20,08.

Temuan penelitian yang menunjukkan bahwa Model pembelajaran kooperatif tipe TSTS melalui lesson study berpengaruh terhadap hasil belajar IPA siswa dengan kecenderungan sebagian besar skor siswa tinggi disebabkan oleh beberapa faktor. Faktor pertama, model TSTS dapat untuk saling bekerjasama antar kelompok, berdiskusi dengan pasanganya dan menyampaikan hasil diskusinya terkait konsep-konsep IPA yang dipelajari. Kegiatan berpikir akan mengarahkan siswa untuk mengeluarkan pendapatnya dalam berkelompok dan rasa tanggung jawab antar kelompok. Kegiatan diskusi bepasangan akan menambah keyakinan siswa terhadap hasil pemikirannya. Selanjutnya, kegiatan sharing atau menyampaikan hasil pemikiran kepada teman sekelasnya akan menambah ingatan siswa terkait pemahamannya terhadap konsep. Ketiga kegiatan tersebut dapat memotivasi siswa untuk belajar lebih baik dan menemukan hal-hal yang bermakna dari kegiatan tersebut. Kesempatan tersebut akan memunculkan hasil pemikiran siswa secara murni dan didukung oleh penguatan dari kelompoknya, sehingga berpengaruh terhadap kualitas pemahaman konsep siswa. Hal lain yang terjadi adalah pemahaman yang diperoleh tersebut tidak mudah dilupakan karena proses yang siswa lalui untuk memperolehnya merupakan kegiatan pembelajaran yang bermakna. Temuan tersebut didukung oleh pendapat Aris Shoimin (2014:208) juga menyatakan bahwa TSTS merupakan suatu "model pembelajaran kooperatif yang memberi siswa waktu saling bekerjasama untuk berdiskusi serta saling bantu satu sama lain". Prosedur tersebut memberikan waktu yang cukup bagi siswa untuk mengkontruksikan pengetahuannya secara bermakna.

Faktor kedua, perpaduan model TSTS melalui Lesson Study memberikan kesan yang berbeda pada pembelajaran. Lesson Study yang dimaksud dalam penelitian ini adalah suatu model pembinaan profesi pendidik melalui pengkajian pembelajaran secara kolaboratif dan berkelanjutan berlandaskan prinsip-prinsip kolegalitas dan mutual learning untuk membangun komunitas belajar. Model Pembelajaran Kooperatif Tipe Two Stay Two Stray melalui Lesson Study terlihat lebih baik dibandingkan pembelajaran secara konvensional dalam pengajaran dijadikan sebagai perantara untuk menyampaikan pesan atau informasi dalam pembelajaran yang dapat merangsang pikiran, perasaan, perhatian dan kemauan siswa sehingga dapat mendorong terjadinya proses belajar pada diri siswa. Sehingga terlihat lebih aktif dan antusias dalam belajar.

Temuan penelitian tersebut sesuai dengan hasil penelitian sebelumnya yang dilakukan oleh Cici Fitrayatun Karlina (2017). Dalam penelitiannya tersebut, dibuktikan bahwa pada model ini siswa lebih terlihat aktif dalam pembelajaran, siswa menemukan sendiri ide dan konsep melalui eksplorasi masalah-masalah nyata. Penelitian serupa juga dilakukan oleh Luh Komang Laksmi Prasatya (2017). Dalam "Pengaruh Model Pembelajaran Two Stay Two Stray (TSTS) Berbasis Masalah Terhadap Hasil Belajar IPA Siswa Kelas V Di Gugus IV Kecamatan Banjar Tahun Pelajaran 2016/2017".. Dalam penelitian tersebut dibuktikan bahwa setelah dibelajarkan dengan menggunakan model pembelajaran (TSTS) berbasis masalah, hasil belajar IPA siswa mengalami peningkatan yang sangat tinggi apabila dibandingkan dengan pembelajaran yang tidak menggunakan model (TSTS). Penelitian mengenai TSTS juga telah dilakukan oleh Trishna Ayudya Pratiwi, (2017). Keberhasilan penelitian-penelitian tersebut mendukung keberhasilan penelitian tentang pengaruh model pembelajaran TSTS melalui Lesson Study terhadap hasil belajar IPA siswa.

Berdasarkan paparan di atas, maka dapat disimpulkan bahwa model pembelajaran kooperatif tipe TSTS melalui lesson study berpengaruh terhadap hasil belajar IPA siswa. 


\section{Simpulan dan Saran}

Berdasarkan hasil penelitian dan pembahasan, dapat disimpulkan bahwa terdapat perbedaan yang signifikan hasil belajar IPA antara siswa yang dibelajarkan dengan model pembelajaran kooperatif tipe TSTS melalui Lesson Study dan siswa yang tidak belajar dengan model pembelajaran kooperatif tipe TSTS melalui lesson study pada siswa kelas V Semester Genap Di SD Negeri 2 Anturan Kecamatan Buleleng Tahun Pelajaran 2017/2018. Hal tersebut diperoleh dari Hasil uji-t menunjukkan bahwa thitung adalah 2,17, sedangkan ttabel pada taraf signifikansi $5 \%$ dan $\mathrm{db}=55$ adalah 2,021. Di samping itu, rata-rata skor hasil belajar IPA siswa yang belajar dengan model pembelajaran kooperatif tipe TSTS melalui lesson study $(24,03)$ lebih tinggi dari pada rata-rata skor siswa yang tidak belajar dengan model pembelajaran kooperatif tipe TSTS melalui lesson study $(20,08)$.

Berdasarkan hasil penelitian dan pembahasan di atas, dapat disimpulkan bahwa terdapat perbedaan yang signifikan pada hasil belajar IPA antara siswa yang belajar dengan model pembelajaran kooperatif tipe Two Stay Two Stray melalui Lesson Study dan siswa yang tidak belajar dengan model pembelajaran kooperatif tipe Two Stay Two Stray melalui Lesson Study pada siswa kelas V Semester Genap di SD Negeri 2 Anturan Kecamatan Buleleng Tahun Pelajaran 2017/2018. Saran-saran yang dapat disampaikan berdasarkan penelitian yang telah dilakukan adalah 1) Disarankan kepada siswa agar lebih memotivasi diri dan lebih aktif dalam mengikuti pembelajaran yang diberikan guru, sehingga dapat meningkatkan hasil belajar pada setiap mata pelajaran. 2) Disarankan kepada guru agar lebih berinovasi dalam pembelajaran dan menerapakan model TSTS melalui Lesson Study karena hasil penelitian membuktikan bahwa penggunaan model TSTS melalui Lesson Study mampu meningkatkan hasil belajar serta motivasi berprestasi siswa. 3) Disarankan kepada kepala sekolah agar dapat menggunakan hasil penelitian ini sebagai bahan acuan pedoman untuk membimbing guru-guru dalam melaksanakan pembelajaran dengan menggunakan model pembelajaran untuk meningkatkan hasil belajar dan motivasi berprestasi siswa. 4) Disarankan kepada peneliti lain agar hasil penelitian ini dapat digunakan sebagai acuan kepustakaan untuk melakukan penelitian dalam variabel yang sama ataupun pada variabel yang berbeda.

\section{Daftar Pustaka}

Aris Shoimin. 2014. 68 Model Pembelajaran Inovatif dalam Kurikulum 2013. Yogyakarta: ArRuzz Media.

Daryanto. 2012. Model Pembelajaran Inovatif. Yogyakarta: Penerbit Gava Media.

Dantes, N. 2012. Metode Penelitian. (P. Christian, Ed.). Yogyakarta: Andi Yogyakarta.

Huda, M. 2014. Model-model Pengajaran dan Pembelajaran. Malang: Pustaka Pelajar.

Karlina, C. F. 2017. Pembelajaran Kooperatif Tipe (TSTS) Berbantuan Peta Pikiran Untuk Meningkatkan Hasil Belajar IPA Melalui Lesson Study. Retrievedfrom http://ejournal.undiksha.ac.id/index.php/JJPGSD/article/download/10883/6960

Laksmi. 2017. Pengaruh Model Pembelajaran TSTS Berbasis Masalah Terhadap Hasil Belajar IPA Siswa Kelas V, 5(2), $2017 . \quad$ Retrieved from http://ejournal.undiksha.ac.id/index.php/JJPGSD/article/download/11004/7055

Pratiwi, T. A. 2017. Pengaruh Model Pembelajaran Cooperative TSTS Berbantuan Peta Konsep Terhadap Kompetensi Pengetahuan IPA Siswa KelasV.Retrievedfrom https://ejournal.undiksha.ac.id/index.php/JJPGSD/article/viewFile/10810/6912 
Trianto. 2007. Model Pembelajaran Terpadu dalam Teori dan Praktek. Jakarta: Prestasi Pustaka.

UU No 20 tahun 2003. 2003. Undang-undang sistem pendidikan nasional. Retrieved from http://eprints.dinus.ac.id/14666/1/uu_20-2003_sisdiknas.pdf 